\title{
SOL-GEL / DIP COATING TECHNIQUE FOR CORROSION PROTECTION OF PETROLEUM PIPELINE STEEL
}

\author{
Mahmoud A. Agour ${ }^{1 *}$, Mohamed K. Hassan ${ }^{1}$, H. Abu El-Ainin ${ }^{1}$, Mohammed S. khalaf ${ }^{2}$, Abdalla \\ Abdal-hay ${ }^{2}$ \\ ${ }^{1}$ Production Engineering \& Design Department, Faculty of Engineering, Minia University, 61111 El-Minia, Egypt; \\ ${ }^{2}$ Department of Engineering Materials and Mechanical Design, Faculty of Engineering, South Valley University, Qena \\ 83523, Egypt, \\ *Corresponding author Email: mahmoud1.agour@gmail.com
}

\begin{abstract}
In the oil, gas and petrochemical industries the greatest costs are those associated with material failures due directly to corrosive-erosive degradation of surfaces and components of the pipelines. These results in the frequent repair and replacement of parts which accrues costs associated with loss in revenues in downtime and maintenance [1]. In the current study, a dip-coating method was exploited to provide a coating layer of epoxy resin on 316L and 304 stainless steel plate. Epoxy resin was converted to cationic tertiary type amine resin. This cationic epoxy resin, which contains ammonium group in the end of the polymer chain, was synthesized by ring-opening reaction of an epoxy resin with secondary amine in the presence of a proton donor. A layer of resin was successfully deposited on the stainless steel plates and physical properties of the layer were assessed. A detailed study aiming to obtain reliable information of coating properties was carried out. The electrochemical corrosion results showed that epoxy layer has a positive behavior on protections of stainless steels alloys at the early degradation time point. Scanning electron microscopy observation was also used to study the surface morphology before and after coating. Tafel extrapolation method and Tafel slope constants were used to calculate the polarization resistance.
\end{abstract}

Keywords: Stainless steels, Corrosion resistance, Scanning electron microscopy, Corrosion analysis, Sol-Gel, Dip-coating.

\section{INTRODUCTION}

In any civilized society, the varying forms of surface coatings are used in different areas of everyday life. They are used mainly for two purposes. The first one is the protection of materials from chemical and physical external attacks, and the other one is the decoration of objects for attractive appearance. The protective function includes resistance against weather damage, decay and

Received:3 February, 2020, Accepted: 29 February, 2020 corrosion, combined with improved superficial mechanical properties, such as greater impact and abrasion resistance. The decorative effect may be obtained through color, gloss or texture. Sea water desalination plants can suffer numerous corrosion problems due to the aggressive environments to which metals are exposed. Furthermore, corrosion deposits on surfaces can also result in a loss in efficiency and performance of certain critical processing equipment such as heat exchangers. 


\section{Vol. 40, No. 1. January 2021}

Coatings are being used where components are subjected to severe wear by abrasive and erosion conditions and these are based on hard overlays, such as conventional Nickel-based and tungsten carbide Ni-WC composites. The deposition of these surface coatings is based on the use of the plasma transferred arc process which is a fusion welding technique and involves complete melting of the coating materials with the surface being coated. The process results in significant changes within the surface of the steel being treated, but also causes complete dissolution of the hard reinforcement of Tungsten carbide (WC) placed into the coating. The overall mechanical properties of the coating are reduced, but also the surface is exposed to melting and solidification which changes its composition and lowers corrosion resistance.

Organic coatings using epoxy resin are considered as an ideal candidate for such this application that has a harsh environment. Epoxy resins can be formulated to yield a variety of properties ranging from soft, flexible materials, too hard, tough, chemical resistant products. They can be modified into low viscosity liquids for easy pouring or converted to solid compositions for laminating and molding applications [2, 3]. Formulation when their superior properties are required. These properties include outstanding water resistance, good chemical resistance, particularly to alkaline environments, outstanding adhesion to a variety of substrates, excellent toughness, hardness and flexibility[4]. In addition, cured epoxy resins have good mechanical and electrical properties, superior dimensional stability, and good resistance to heat and chemical attack $[4,5]$

\section{MATERIALS AND METHODS}

\subsection{Sample preparation}

Steel sheet was cut into square pieces $(12 \times 12$ $\mathrm{mm}^{2}$ and $2 \mathrm{~mm}$ in thickness) as shown in Fig.1.

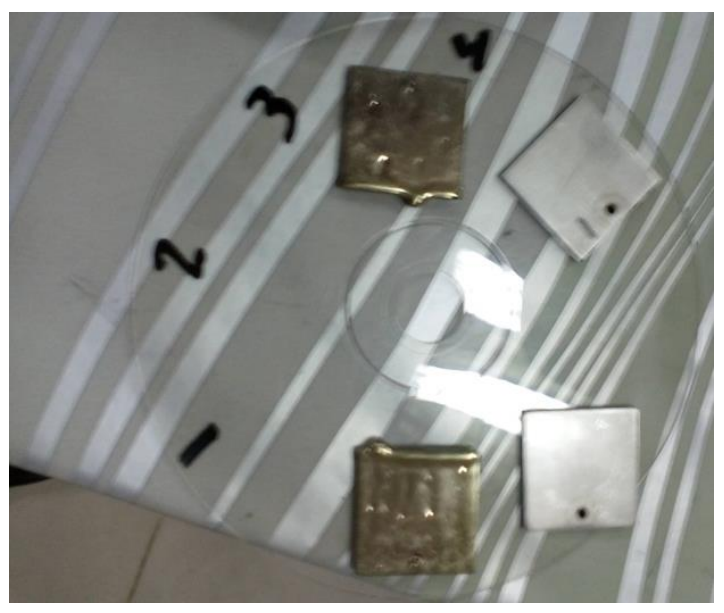

Fig.1 2-D image of the treated samples in the present study.

Before coating, the AISI steel samples were pre-treated as follows: (1) first, they were grinded and polished mechanically with silicon carbide papers (800-1500 grits) and soft cloths to ensure the same surface roughness, then they were (2) cleaned ultrasonically in acetone for 5 min to remove residual grease and distilled water and dried in a normal dryer at $150{ }^{\circ} \mathrm{C}$.

\subsection{Preparation of the coating layer}

The deposited Epoxy layer was prepared by a dip-coating method with suitable modifications. Commercial grade cycloaliphatic epoxy resin (YD-128), a pale yellow viscous liquid, and D-230 hardener were used in this study. Epoxy solutions with 10 wt $\%$ hardener were prepared. All the specimens (before dip-coatings) were kept over a hot plate at $160{ }^{\circ} \mathrm{C}$ for $10 \mathrm{~min}$ to remove moisture and entrapped air from the substrate surfaces. The prepared substrates were immersed into the prepared solutions for $30 \mathrm{~s}$ to allow wetting of the substrate. In order to obtain a stain-free surface, the specimens were mechanically pulled slowly out of the solution at a speed of $2 \mathrm{~mm} / \mathrm{s}$. The motor 
lifting the substrate worked continuously and was vibration-free. All the coated samples were dried with a vacuum drier (10 mbar).Then surface morphology was examined using scanning electron microscopy (SEM) equipped with an energy dispersive spectrometer (EDS).

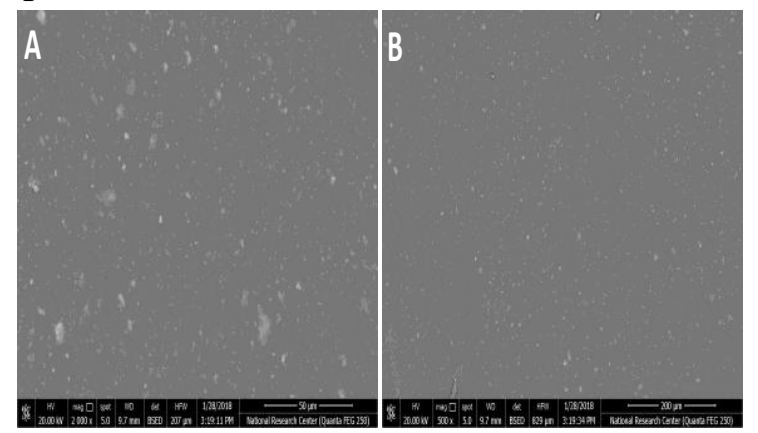

Fig.2. Scanning electron microscope images of St. 416L coated with epoxy resin at low (A) and high (B) magnification images.

The SEM describes that the coating was uniform with smooth and free defects or voids as shown in Fig. 2. It is expected that the thickness of the coatings might be high due to the high viscosity of the epoxy resin. The thickness of the coatings was assessed by measuring the total thickness if the samples before and after deposition of epoxy resin. The coatings thickness was about $500 \mu \mathrm{m}$.

Figs. 3, 4 display the elemental analysis (EDS) of the coated surface of 316L and 304 stainless steels substrates and their elemental quantities are attached below the corresponding figures. The differences in a chemical composition between the two types of substrates are that the $316 \mathrm{~L}$ has a lower carbon content compared with the 304 samples. As we can see a carbon peak with strong intensity is appeared on the both coated samples, which indicate the precipitation of epoxy organic layer on the surface of stainless steel alloys.

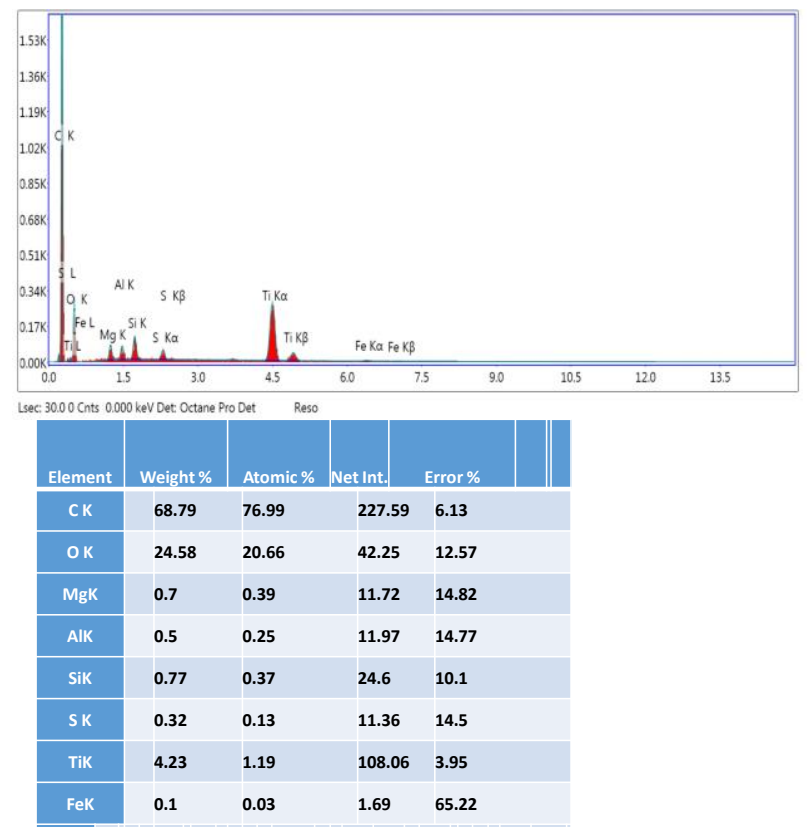

Fig.3 EDS elemental analysis of St. 304 sample coated with epoxy resin.

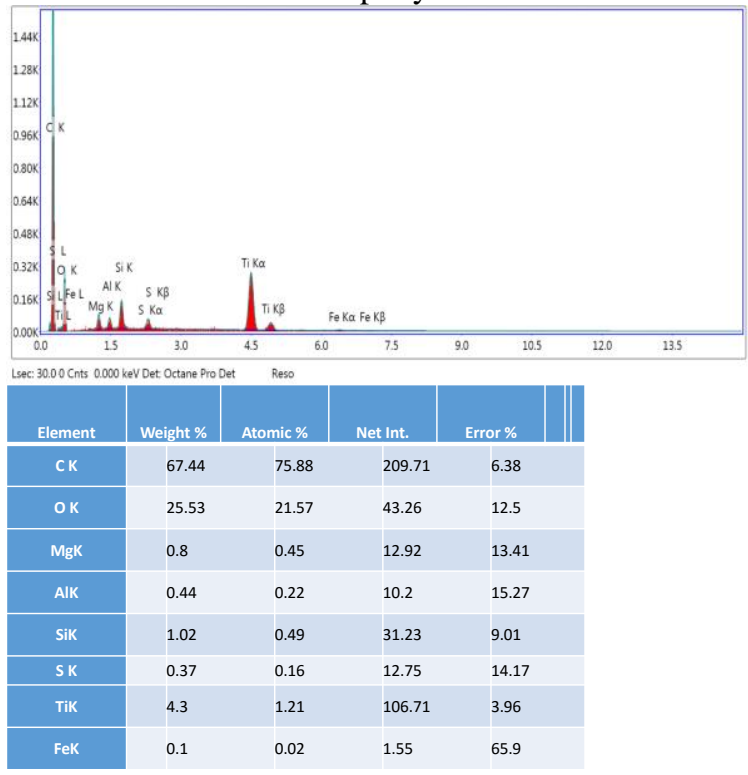

Fig.4 EDS elemental analysis of St. 416L sample coated with epoxy resin.

For harsh environmental applications, the corrosion resistance of pipelines is a very important factor [6-8], therefore the electrochemical behaviors of both the control and coated samples were investigated using a potentiodynamic polarization test (263A, EG\&G PAR, USA). Prior to polarization test, the samples were immersed in $1000 \mathrm{ml}$ 
artificial seawater-like $(3.5 \% \mathrm{NaCl})$ for 20 min. A three-electrode cell was constructed to perform the test with the samples used as the working electrode, saturated potassium chloride electrode as the reference electrode, and platinum as the counter electrode. The exposed area of the working electrode (control and deposited samples) to the solution was $0.785 \mathrm{~cm}^{2}$. A scanning rate of $1 \mathrm{mVs}^{-1}$ was applied during the test, which started at -160 $\mathrm{mV}$. The changes in the free corrosion potential were recorded as a function of time. The corrosion potential (Ecorr), corrosion current density (Icorr), anodic and cathodic Tafel slopes ( $\beta \mathrm{a}$ and $\beta \mathrm{c})$,were determined from the polarization curves using Tafel extrapolation method and Tafel slope constants were used to calculate the polarization resistance ( $\mathrm{Rp}$ ) according to Eq. (1) [9-11].

$$
R p=\frac{1}{2.303 \operatorname{Icorr}\left(\frac{B c * B a}{B c+B a}\right)}
$$

\section{RESULTS AND DISCUSSIONS}

Table. 1 presents the corrosion parameters obtained from the potentiodynamic polarization curves.

\begin{tabular}{|c|c|c|c|c|}
\hline $\begin{array}{c}\mathbf{B}_{\mathbf{a}} \\
(\mathrm{mV})\end{array}$ & $\begin{array}{c}\mathbf{B}_{\mathbf{c}} \\
(\mathrm{mV})\end{array}$ & $\begin{array}{c}\mathrm{I}_{\text {corr }} \\
\left(\mathrm{nA} / \mathrm{cm}^{2}\right)\end{array}$ & $\begin{array}{c}\mathrm{E}_{\text {corr }} \\
(\mathrm{mV})\end{array}$ & $\begin{array}{c}\text { Corrosion } \\
\text { rate }(\mu \mathrm{m} / \mathrm{Y})\end{array}$ \\
\hline \multicolumn{5}{|c|}{ specimen 1 (304) } \\
\hline 140.6 & -68 & 263.9 & -385.6 & 2.044 \\
\hline \multicolumn{5}{|c|}{ specimen 2 (316L) } \\
\hline 133.4 & -74.7 & 198 & -251 & 1.534 \\
\hline \multicolumn{5}{|c|}{ specimen 3 (304 Coating) } \\
\hline 93 & -79.4 & 1.5886 & 20.9 & $12.30 * 10^{\wedge}-3$ \\
\hline \multicolumn{5}{|c|}{ specimen 4(316L Coating) } \\
\hline 107 & -110.1 & 49.4974 & 248.6 & 0.383 \\
\hline
\end{tabular}

Representative

Potentiodynamic polarization curves obtained from the uncoated and coated AISI steel samples with epoxy resin layer are presented in Fig. 5 The corrosion potential $\left(\mathrm{E}_{\mathrm{Corr}}\right)$ values are listed in

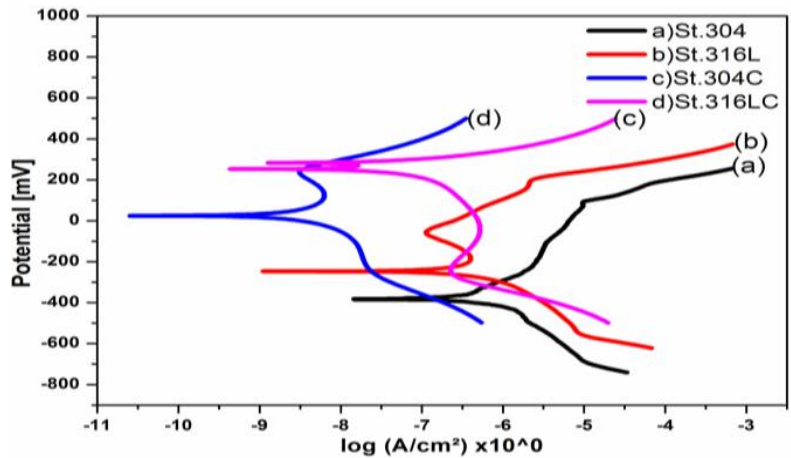

Fig. 5 Potentiodynamic polarization curves of the control sample and samples coated with epoxy matrix layer.

Table. 1. In general, the $\mathrm{E}_{\mathrm{Corr}}$ is shifted to the positive side by epoxy polymer-coated steel alloys. At the same time, the values of the corrosion current $\left(\mathrm{I}_{\text {corr }}\right)$ of the polymer layers (especially 316L sample significantly decreased by more than three orders of magnitude as to the uncoated sample. This kind of oscillation has also been found in the literature[12] in the case of polymer layers present in saline medium and was attributed to the competition between deposited polymer layers and water penetration of St. substrates. It seems that due to the high purity and low carbon content of $316 \mathrm{~L}$ samples had better corrosion resistance than 304 substrates.

\section{CONCLUSION}

In this research, we successfully fabricated an organic layer composed of epoxy resin as an adhesive flexible polymer coating using the dipping technique on two different stainless steels, St. 316L and 304 substrates. The results documented that the rough surface had a significant effect on coating performance. The coatings prepared using epoxy resin after aging for 24 hours to provide a cross linking are exceptional in their ability to generate smooth and uniform morphology at the two different substrates. The results bring together that the formed coatings layer on St Substrates are relatively smooth and free voids and defects on the formed organic layer. Tiny pits 


\section{Vol. 40, No. 1. January 2021}

were generated after immersion of these samples in saline solution for 30 days, whereas untreated samples underwent severe localized corrosion which is one considered parameter in need to further investigating in a future study. The results also showed that the organic coating by epoxy resin layer plays an important in controlling the corrosion resistance and works as an a protective anticorrosive layer on the surface of St alloys which is a good proof that layer is stable enough in a harsh saline environment.

\section{REFERENCES}

[1] Shadravan, A. and M. Amani, HPHT 101-what petroleum engineers and geoscientists should know about high pressure high temperature wells environment. Energy Science and Technology, 2012. 4(2): p. 36-60.

[2] Arias, S.C.L., Ethnogeology at the Core of Basic and Applied Research: Surface Water Systems and Mode of Action of a Natural Antibacterial Clay of the Colombian Amazon. 2016: Arizona State University.

[3] Vijjamarri, S., V.K. Chidara, and G. Du, Versatile Manganese Catalysis for the Synthesis of Poly (silylether) s from Diols and Dicarbonyls with Hydrosilanes. ACS omega, 2017. 2(2): p. 582-591.

[4] Lee, Y.-H., et al., Synthesis and properties of flexible polyester with urethane polyol for automotive pre-coated metals. Journal of adhesion science and Technology, 2016. 30(14): p. 15371554.

[5] Killilea, T.H. and J.M. Bohannon, Coating compositions containing reactive diluents and methods. 2016, Google Patents.
[6] Niespodziana, K., et al., Fabrication and properties of titanium-hydroxyapatite nanocomposites. Materials Chemistry and Physics, 2010. 123(1): p. 160-165.

[7] Shukla, A. and R. Balasubramaniam, Effect of surface treatment on electrochemical behavior of $\mathrm{CP} \mathrm{Ti}$, Ti-6Al-4V and $\mathrm{Ti}-13 \mathrm{Nb}-13 \mathrm{Zr}$ alloys in simulated human body fluid. Corrosion Science, 2006. 48(7): p. 1696-1720.

[8] Instruments, G., Getting Started with Electrochemical Corrosion Measurement. Gamry Instruments: Warminster, PA, USA, 2011.

[9] Abdal-Hay, A., et al., Biocorrosion behavior of biodegradable nanocomposite fibers coated layer-by-layer on AM50 magnesium implant. Materials Science and Engineering: C, 2016. 58: p. 1232-1241.

[10] Hynowska, A., et al., Nanostructured $\beta$-phase Ti-31.0 Fe-9.0 Sn and sub- $\mu \mathrm{m}$ structured $\mathrm{Ti}-39.3 \mathrm{Nb}-13.3 \mathrm{Zr}-10.7 \mathrm{Ta}$ alloys for biomedical applications: Microstructure benefits on the mechanical and corrosion performances. Materials Science and Engineering: C, 2012. 32(8): p. 2418-2425.

[11] G102-89, A., Standard practice for calculation of corrosion rates and related information from electrochemical measurements. Reapproved 1999, 1999.

[12] Abdal-hay, A., M.-G. Hwang, and J.K. Lim, In vitro bioactivity of titanium implants coated with bicomponent hybrid biodegradable polymers. Journal of sol-gel science and technology, 2012. 64(3): p. 756-764. 
Vol. 40, No. 1. January 2021 
يقدم هذا البحث دراسة معملية لتحسيين خواص التاكل لسطح خطوط الانابيب المستخدمة فى نقل مواد البترول الخام منها والمعالج وكذلك فى المياة المالحة حتى يجرى لها عملية المعالجة تم استخدام مادة الايبوكسى البوليمرية كمادة طلاء على اسطح المعدن حيث تعتبر هذة المادة من اقوى المواد اللاصقة وخاصة على اسطح المعدن. حيث أنه توجد العديد من الطرق لعملية الطلاء للمواد البوليمرية على اسطح المعادن مثل نفخ الهواء والغزل وكذلك الغمر • وحيث ان طريقة الغمر لها مميزات عدة بالمقارنة بتلك الطرق المستخدمة من حيث السهولة ورخص التكلفة وكذلك قدرة تلك التقنية على تغطية سطح المادة المراد طلائها من جميع الجوانب فى ان واحد عكس الطرق التقليدية والتى تفتقر الى تلك الخاصية. تم طلاء اسطح المعدنيين بمادة الاييوكسى فى حرارة الغرفة بعد غمر المعدن لمدة •r ثانية فى مادة الايبوكسى. تم فحص اسطح طبقة الطلاء بالماسح الاكترونى الدقيق وذلك لمعرفة اذا كان سطح الطلاء بة اى عيوب او تلف قبل وبعد الطلاء. بينت النتائج ان السطح المطلى خالى من الى عيوب تماما وليس به فجوات او خدوش. تم دراسة خواص التاكل باستخدام جهاز تحليل التاكل الدقييق اظهرت النتائج قدرة مادة الايبوكسى على تحسيين خواص الطلاء بشكل كبيير مما يرشح تلك المادة والطريقة لمعالجة اسطح خطوط الانابييب البترولية. 